Anal ysi s of i mpact response of sand cushi on for rockfal I by di sti nct el ement method

\begin{tabular}{|l|l|}
\hline 著者 & $\begin{array}{l}\text { Wat anabe Takashi , Nasuya Hi roshi, Sat oh Aki ra, } \\
\text { Nakamur a Sachi o }\end{array}$ \\
\hline $\begin{array}{l}\text { j our nal or } \\
\text { publ i cat i on ti tl e }\end{array}$ & Appl i ed Mechani cs and Nat er i al s \\
\hline vol une & 82 \\
\hline page r ange & $92-99$ \\
\hline year & 2011- 01-01 \\
\hline URL & ht t p: //hdl . handl e. net /2297/29297 \\
\hline
\end{tabular}




\title{
Analysis of Impact Response of Sand Cushion for Rockfall by Distinct Element Method
}

\author{
Takashi Watanabe ${ }^{1, a}$, Hiroshi Masuya ${ }^{2, b}$, Akira Satoh ${ }^{3, c}$ and \\ Sachio Nakamura ${ }^{3, d}$ \\ ${ }^{1}$ Kozo Keikaku Engineering Inc., Seismic \& Environmental Engineering Department, Chuo 4-5-3, \\ Nakano-ku, Tokyo, 164-0011, Japan \\ ${ }^{2}$ Kanazawa University, Institute of Science and Engineering, Faculty of Environmental Design, \\ Kakuma-machi, Kanazawa, 920-1192, Japan \\ ${ }^{3}$ Nihon Samicon Co. Ltd., Department of Technology Research, Bentenbashi-dori 1-8-23, Tyuo-ku, \\ Niigata, 950-0925 Japan \\ a takashi-watanabe@kke.co.jp, ${ }^{\mathrm{b}}$ masuya@kenroku.kanazawa-u.ac.jp, \\ c a-sato@nihon-samicon.co.jp, ${ }^{c}$ nakamura@nihon-samicon.co.jp,
}

Keywords: Rockfall, Sand cushion, Distinct Element Method, Shape of rock, Randomness of sand

\begin{abstract}
In order to know efficiently the impact behavior of the actual size sand cushion under rock fall, to achieve a lot of impact experiments under various conditions or to analyze those phenomena by use of reliable accurate methods is generally required. However, there is difficulty in many cases to achieve experiments because of financial reason. Therefore, the analysis method to reproduce full-scale impact behavior is indispensable. From this point of view, we have developed Distinct Element Method. The method to model the body to collide like a rock fall by an assembly of many small elements and the method to present a sand cushion as an assembly of many elements which have different size with randomness were shown. The validity of this method was shown by the comparison with experimental results.
\end{abstract}

\section{Introduction}

Japan has sometimes earthquake and much rain areas. The structure built in the mountainous area has the risk of the natural disaster such as a landslide or a rockfall. Therefore various preventive measures against natural disasters have been taken until the present. Protect structure against rockfall should be designed so that it has the sufficient bearing capacity to the large energy expected. Shock absorbing material such as sand is often laid on the upper surface of the structure like a rock shed in order to make impact force less. However, evaluation of the impact force transmitted to a structure through such shock absorbing material has not been sufficiently clarified [1,2,3]. Since it is considered that theoretical accurate explanation is generally difficult for such an impact action under various collision conditions, an explication by experimental or analytical research is desired. Also the utilization of highly reliable analysis technique is also required to clarify the limit state of a protection structure and carry out performance based design [4,5].

Consequently, series of impact experiments and numerical analyses using Distinct Element Method were carried out to grasp impact behavior of sand cushion in this study. Impact experiments had been done by the free drop of a heavy weight on a sand cushion from each predetermined height. The numerical analysis method was investigated to reproduce the experimental results well. In the analysis, the collision body with arbitrary shape like a rock fall was modeled as an assembly of many small elements. And the sand cushion was modeled as an assembly of many elements which have different size to express actual randomness. The validity of this method was shown by the comparison with experimental results. 


\section{Outline of impact experiment}

A series of impact experiment had been carried out using equipment shown in Photo 1 . This equipment size was a steel frame with $2.35 \mathrm{~m}$ in width, $3.5 \mathrm{~m}$ in depth, and $4.5 \mathrm{~m}$ in height. The weight was released from a predetermined height and it was dropped on the center of the sand tank. The sizes of tank inside were all sides about 1.1 meters and it was filled up by the sand of 75 centimeters depth. Thirty-six load cells were installed in total on the bottom area of the sand tank to measure the pressure as shown in Photo 2. The installed area was quarter of the bottom area considering symmetry of the square. The transmitted forces at the bottom were calculated by the superposition of measured pressures. Namely, they were calculated by the method of which the usable area of each part was multiplied by measurements of the load cell. Hereafter, this force was called as transmitted force in this study.

The configuration of the weight used in experiment is shown in Fig. 1. Two different bottom shapes of weight were used and both their weights were $2 \mathrm{kN}$. An accelerometer was installed in top plane of each weight. The impact force acted to the weight at the moment of the collision to the sand cushion was calculated by multiplying the acceleration and the mass of the weight. Hereafter, this force was called as weight impact force in this study.

The condition of experiments is shown in Table 1. Characteristics of the sand are shown in Table 2.
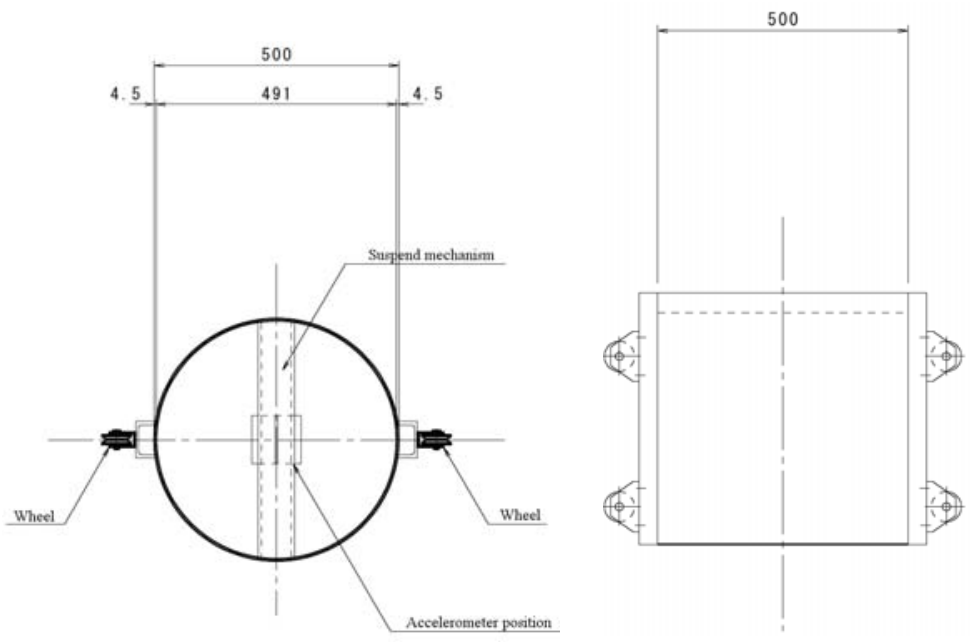

(a) Top view

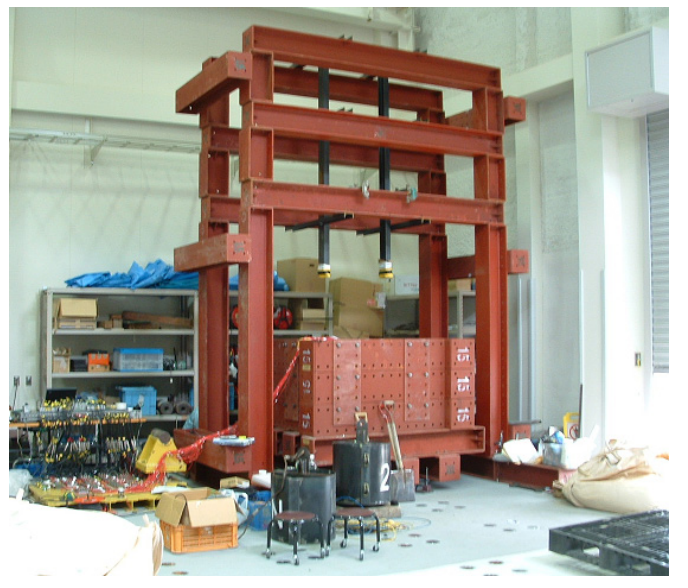

Photo 1 Experimental equipment

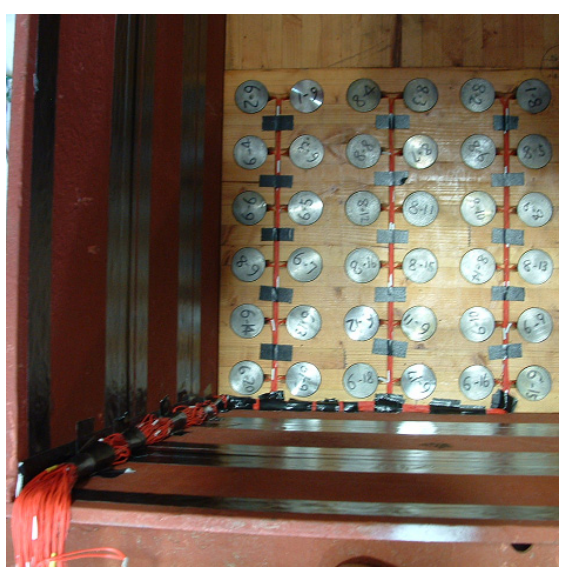

Photo 2 Load cells at the bottom of tank

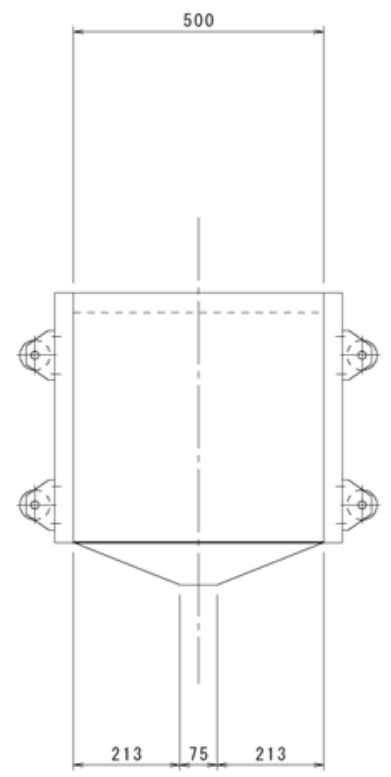

(b) Flat bottom type

(c) Conical bottom type

Fig. 1 Configuration of the weight 


\section{Outline of analysis}

The applicability to an actual problem was examined using the three dimensional program of distinct element method [6,7]. The outline of analysis is briefly described below.
Table 1 Condition of experiments

\begin{tabular}{|c|c|l|}
\hline Weight shape & Sand thickness [cm] & Height of falling [m] \\
\hline \multirow{3}{*}{ Flat } & 30 & $0.5,1.0,1.5$ \\
\cline { 2 - 3 } & 50 & $0.5,1.0,1.5,2.0$ \\
\cline { 2 - 3 } Conical & 70 & $0.5,1.0,1.5,2.0$ \\
\cline { 2 - 3 } & 30 & $0.5,1.0,1.5,2.0,2.5,3.0$ \\
\cline { 2 - 3 } & 50 & $0.5,1.0,1.5,2.0,2.5,3.0$ \\
\hline \multirow{3}{*}{} & 70 & $0.5,1.0,1.5,2.0,2.5$ \\
\hline
\end{tabular}

Table 2 Characteristic values of the sand

\begin{tabular}{|c|c|c|c|c|c|c|c|}
\hline $\begin{array}{c}D_{10} \\
{[\mathrm{~mm}]}\end{array}$ & $\begin{array}{c}D_{30} \\
{[\mathrm{~mm}]}\end{array}$ & $\begin{array}{c}D_{60} \\
{[\mathrm{~mm}]}\end{array}$ & $\begin{array}{c}\text { Effective grain size } \\
(\mathrm{mm})\end{array}$ & $\begin{array}{c}\text { Uniformity } \\
\text { coefficient }\end{array}$ & $\begin{array}{c}\text { Curvature } \\
\text { coefficient }\end{array}$ & $\begin{array}{c}\text { Maximum } \\
\text { void ratio }\end{array}$ & $\begin{array}{c}\text { Minimum } \\
\text { void ratio }\end{array}$ \\
\hline 0.20 & 0.34 & 0.61 & 0.49 & 3.1 & 0.95 & 0.784 & 0.488 \\
\hline
\end{tabular}

Modeling of the weight. In the past study by authors, the weight was modeled as a large sphere element. It was confirmed that the expression of the shape effect such as a weight with flat bottom was difficult. Therefore, a new model was adopted to consider the shape effect in this study. This model was consisted of plural particles of the lattice arrangement using geometry data of the actual weight.

The weight was modeled using particles arranged in a grid by the judgment of each particle coordinate in the inside or outside of the weight shape surface. This modeling is generally straightforward if a weight doesn't have concave surface. However, there are some difficulties for modeling, if it has an arbitrary shape. Therefore, the geometry data was converted into the shape data consisted of only convex surface using Delaunay division. The geometry data of the actual weight and after tetra mesh division are illustrated in Fig. 2. Particle models for two weights are illustrated in Fig. 3. Various values of weight model are shown in Table 3.

It was assumed the weight model was a rigid body in the analysis, because the weight filled with concrete had much higher stiffness than the sand cushion. Every walls of the sand tank were also treated as a rigid body.
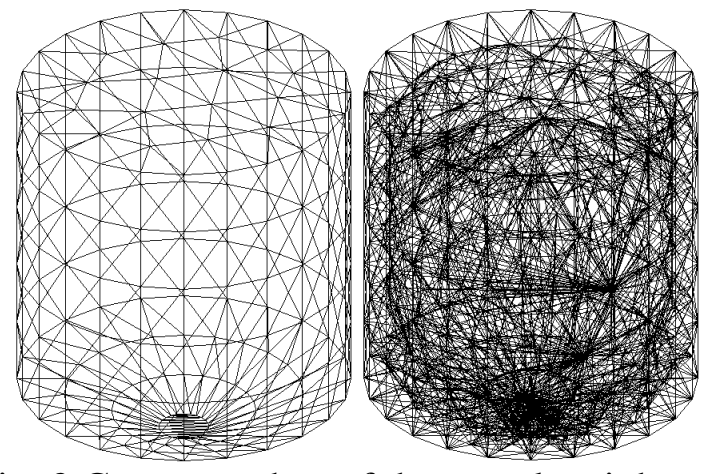

Fig. 2 Geometry data of the actual weight and after tetra mesh division

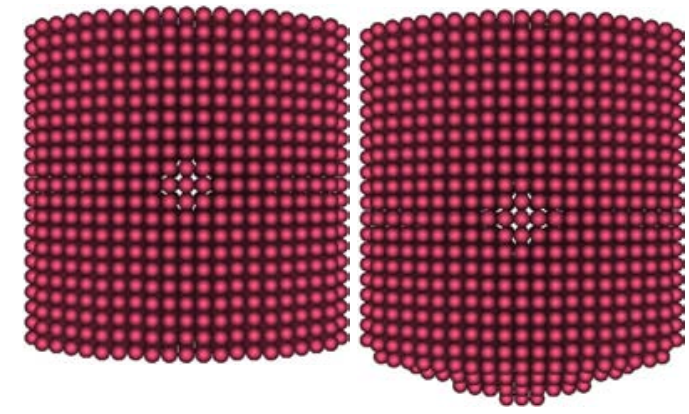

Fig. 3 Particle model of the weight

Table 3 Various values of weight model

\begin{tabular}{|l|r|r|}
\hline Weight shape & \multicolumn{1}{|c|}{ Flat } & \multicolumn{1}{c|}{ Conical } \\
\hline Total mass [kg] & 200.6 & 202.5 \\
\hline Radius [mm] & 12 & 12 \\
\hline No. of pcs [pcs] & 7161 & 7681 \\
\hline Density $\left[\mathrm{kg} / \mathrm{m}^{3}\right.$ ] & 3869.7 & 3642.6 \\
\hline
\end{tabular}

Modeling of the sand cushion and sand tank. In this study, the sand cushion was modeled by sphere elements which have classified different particle size. Because it is generally known that transmission pathway of an impact force becomes monotonous when sand cushion is modeled by the same size elements. However, it is practically difficult to reproduce grain size distribution of the 
actual sand in a numerical analysis. Therefore, a grain size distribution with four particle size was assumed so that mass ratio of those four classes adjusted actual grain size distribution. Three depth models of the sand cushion were made according to each sand thickness by the analysis of free fall motion to pack sand elements. The particle density of each model became $2691 \mathrm{~kg} / \mathrm{m}^{3}(h=70 \mathrm{~cm})$, $2669 \mathrm{~kg} / \mathrm{m}^{3}(h=50 \mathrm{~cm})$ and $2630 \mathrm{~kg} / \mathrm{m}^{3}(h=30 \mathrm{~cm})$ to adjust total mass in each cushion thickness $h$.

It was supposed that sand cushion existed in the space of $1100 \mathrm{~mm} \times 1100 \mathrm{~mm} \times 750 \mathrm{~mm}$ of the sand tank. There were one bottom face and four side faces in sand tank. Therefore, it was assumed that the bottom face consisted of $8 \times 8 \times 2$ triangle wall elements and each side face consisted of $8 \times 8 \times 2$ triangle wall elements. As a result, all faces were modeled by 640 elements in total.

Table 4 shows grain size distributions of the sand cushion model assumed in this study. As an example, the analysis model is for cushion thickness $h=70 \mathrm{~cm}$ is illustrated in Fig. 4.

Table 4 Grain size distributions of the sand cushion model

\begin{tabular}{|c|c|r|r|r|r|r|}
\hline \multirow{2}{*}{ Sand thickness[cm] } & \multicolumn{4}{|c|}{ Radius of particle } & \multirow{2}{*}{ total } \\
\cline { 3 - 7 } & $8.0 \mathrm{~mm}$ & $12 \mathrm{~mm}$ & $16 \mathrm{~mm}$ & $20 \mathrm{~mm}$ & \\
\hline \multirow{2}{*}{$\mathrm{h}=70$} & Number & 37486 & 24302 & 8613 & 4130 & 74531 \\
\cline { 2 - 7 } & Mass ratio[\%] & 14.82 & 32.43 & 27.24 & 25.51 & 100 \\
\hline \multirow{2}{*}{$\mathrm{h}=50$} & Number & 27026 & 17501 & 6145 & 2972 & 53644 \\
\cline { 2 - 7 } & Mass ratio[\%] & 14.87 & 32.51 & 27.06 & 25.56 & 100 \\
\hline \multirow{2}{*}{$\mathrm{h}=30$} & Number & 16379 & 10650 & 3745 & 1770 & 32544 \\
\cline { 2 - 7 } & Mass ratio[\%] & 14.90 & 32.69 & 27.25 & 25.16 & 100 \\
\hline
\end{tabular}

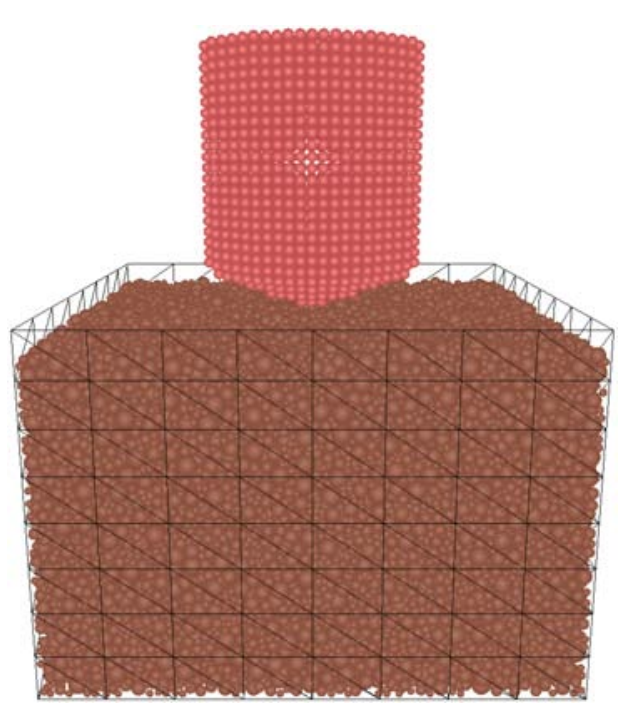

Fig. 4. Analysis model $(h=70 \mathrm{~cm})$

Table 5 List of parameters used in analysis

\begin{tabular}{|c|c|c|c|}
\hline Case name & $\begin{array}{c}\text { Weight } \\
\text { shape }\end{array}$ & $\begin{array}{c}\text { Sand } \\
\text { thickness[cm] }\end{array}$ & $\begin{array}{c}\text { Height of } \\
\text { falling [m] }\end{array}$ \\
\hline JHT30F10 & Flat & 30 & 1.0 \\
\hline JHT30F15 & Flat & 30 & 1.5 \\
\hline JHT50F10 & Flat & 50 & 1.0 \\
\hline JHT50F15 & Flat & 50 & 1.5 \\
\hline JHT70F10 & Flat & 70 & 1.0 \\
\hline JHT70F15 & Flat & 70 & 1.5 \\
\hline JST30F10 & $\begin{array}{c}\text { Conica } \\
\text { l }\end{array}$ & 30 & 1.0 \\
\hline JST30F15 & $\begin{array}{c}\text { Conica } \\
\text { l }\end{array}$ & 30 & 1.5 \\
\hline JST50F10 & $\begin{array}{c}\text { Conica } \\
1\end{array}$ & 50 & 1.0 \\
\hline JST50F15 & $\begin{array}{c}\text { Conica } \\
1\end{array}$ & 50 & 1.5
\end{tabular}

Cases of analysis. A series of analysis were performed by changing the weight shape, the sand thickness, and the falling height as parameters. The fall location was the center of the sand tank in all cases. The list of parameters used in analysis is shown in Table 5. The analysis cases intended for the experiments of fall height $1.0 \mathrm{~m}$ and $1.5 \mathrm{~m}$.

Constants in analysis. Time increment used in this analysis was determined from the results by preliminary analysis to give no affect to the solution. Namely, time increment was set to $1 / 100$ of the natural period $T$ which made a sand element one mass vibration system. In this study, the spring
Table 6 Constants used in analysis

\begin{tabular}{|c|c|}
\hline Normal spring constant & $3.20[\mathrm{kN} / \mathrm{mm}]$ \\
\hline Tangent spring constant & $0.80[\mathrm{kN} / \mathrm{mm}]$ \\
\hline Damping constant & 0.05 \\
\hline Friction angle & $44.5[$ degrees] \\
\hline
\end{tabular}


constants were defined with the trial-and-error method on the basis of the result of JHT70F15. The spring constants depend on particle size. Those are combined by serial composition, when the collision between the different sizes. The used basic constants for analysis are shown in Table 6 . The shown spring constants are for the collision between the smallest particles.

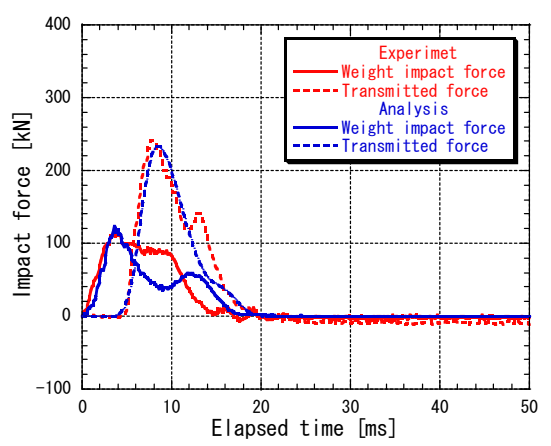

(a)JHT70F10

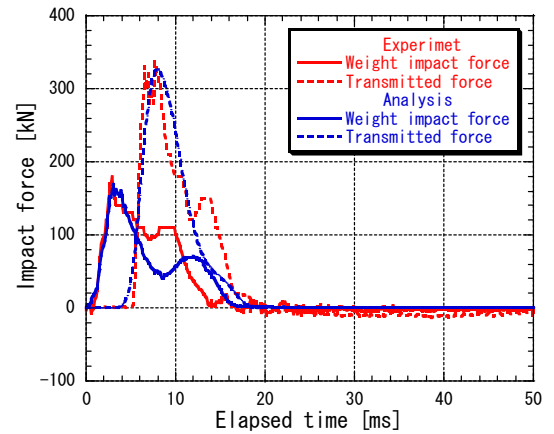

(d)JHT70F15

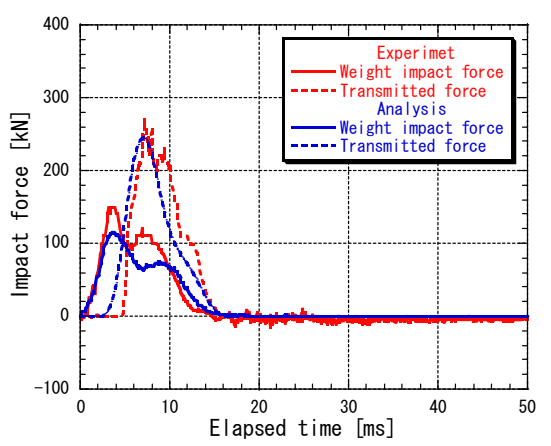

(b)JHT50F10

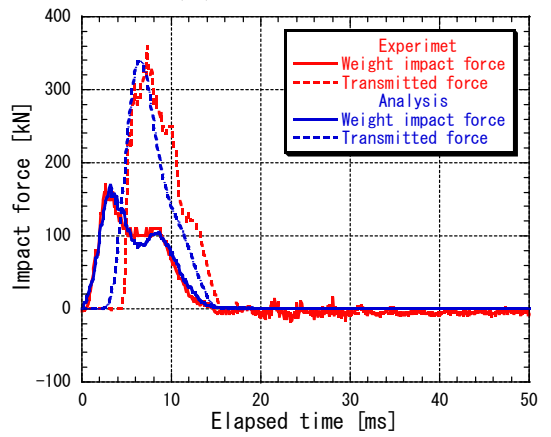

(e)JHT50F15

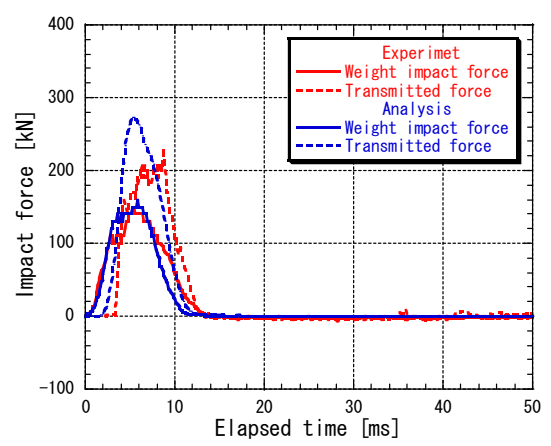

(c)JHT30F10

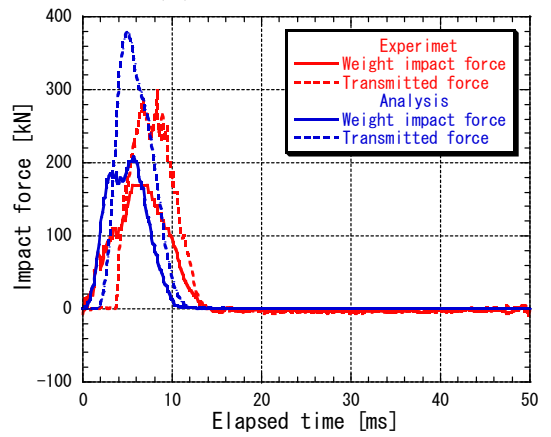

(f)JHT30F15

Fig. 5 Impact force in the case of flat bottom type

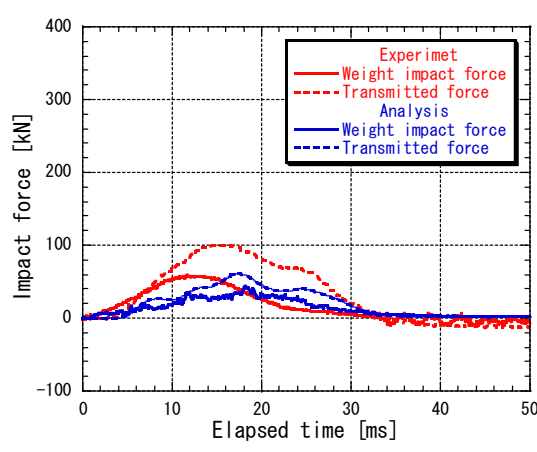

(a)JST70F10

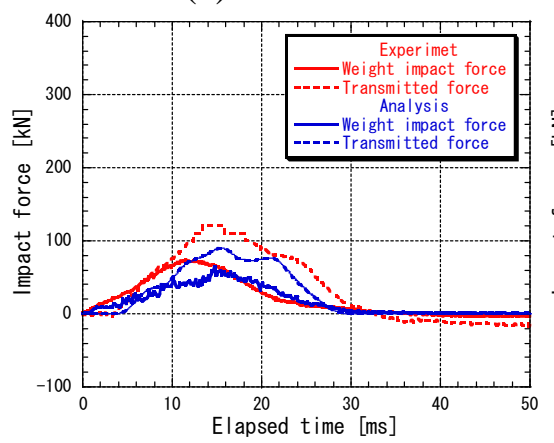

(d)JST70F15

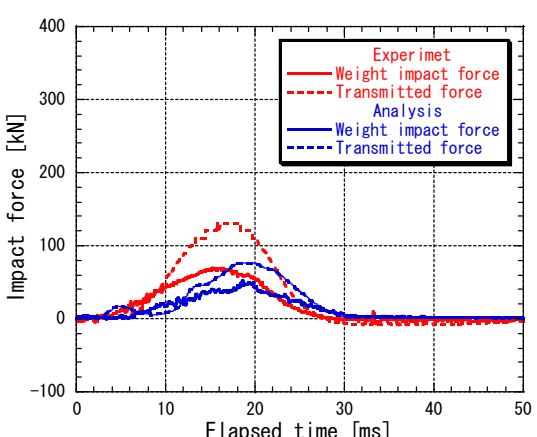

(b)JST50F10

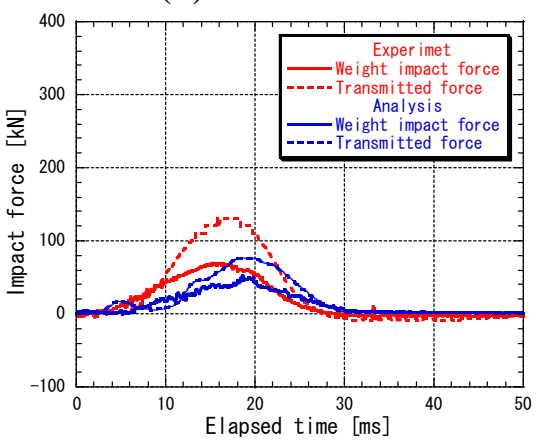

(e)JST50F15

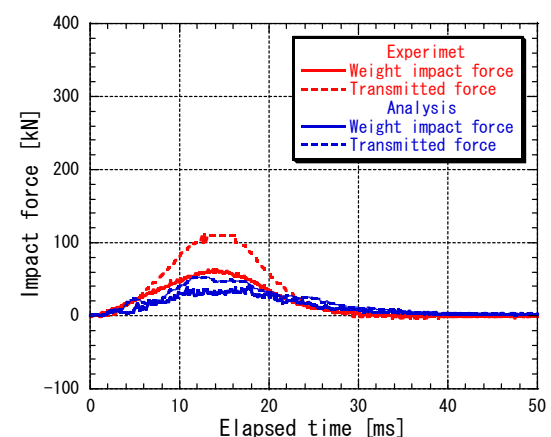

(c)JST30F10

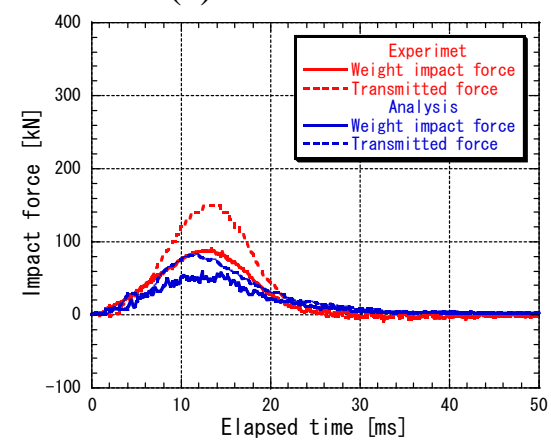

(f)JST30F15

Fig. 6 Impact force in the case of conic bottom type 


\section{Numerical results}

Response of impact force. In this study, two kinds of impact force were used as mentioned in Outline of impact experiment. One is weight impact force, which is calculated from the acceleration and the mass of the weight. Another is transmitted force, which is a summation of values in each multiplying an earth pressure by an effective area. In the analysis, it is calculated as a summation of each normal direction force of elements in object wall plane.

The time histories of impact force in the cases of flat bottom type are shown in Fig. 5 and those in the cases of conical bottom type are shown in Fig. 6. In the case of flat bottom type, it is recognized that an analysis wave pattern agrees well with an experiment wave pattern in both the weight impact force and the transmitted force. It is considered that reproducibility of phenomenon by this method is high and it is confirmed that the uplift process of the weight impact force is reproduced as well as the start of the waveform in cases of sand thickness $70 \mathrm{~cm}$ and $50 \mathrm{~cm}$ in particular.

However, reproducibility of phenomenon is not so well in the case of conical bottom type compared with the case of flat bottom type. It is thought as a cause that the behavior of penetration into the sand cushion at the time of collision affects the result. It is considered important how to express accurately the contact surface between weight and sand cushion by distinct elements. It is expected that reproducibility of phenomenon become better, if much more elements are used for analysis of the sliding process at the contact surface.

Concerning response of impact force, it became clear that this numerical simulation method has been done successfully to reproduce the experimental result. It also confirmed by this numerical simulation method that the maximum of the transmitted impact force at the bottom of the sand cushion is almost twice of the weight impact force, which had been observed as an experimental fact.

Behavior of sand cushion. Figure 7 shows time histories of penetrating process of the weight into the sand cushion at the center section in case of JHT50F15. From the figure, a visual representation of

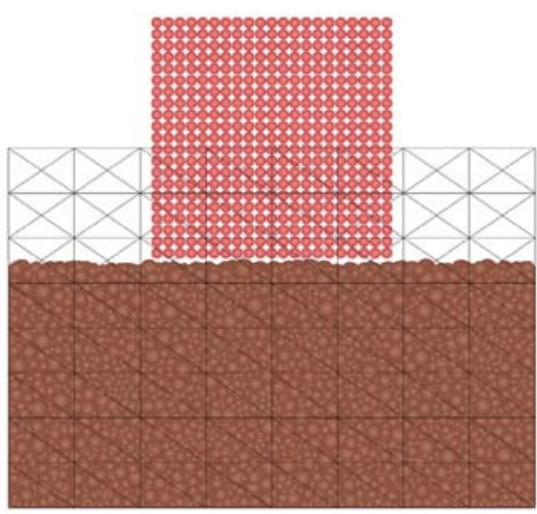

(a) $\mathrm{t}=0.0 \mathrm{~ms}$

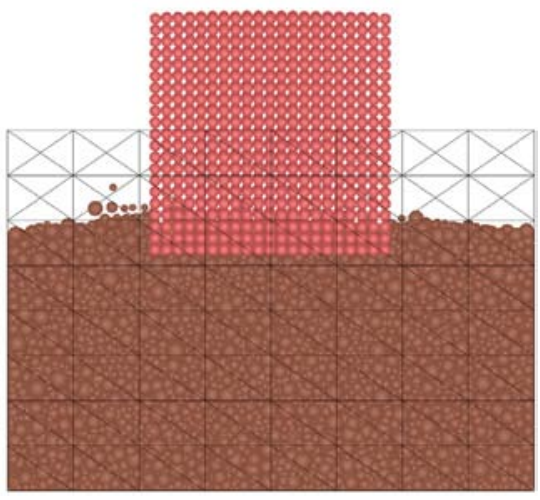

(d) $\mathrm{t}=30.0 \mathrm{~ms}$

Fig. 7 Time histories of the penetrating process of the weight into the sand cushion.

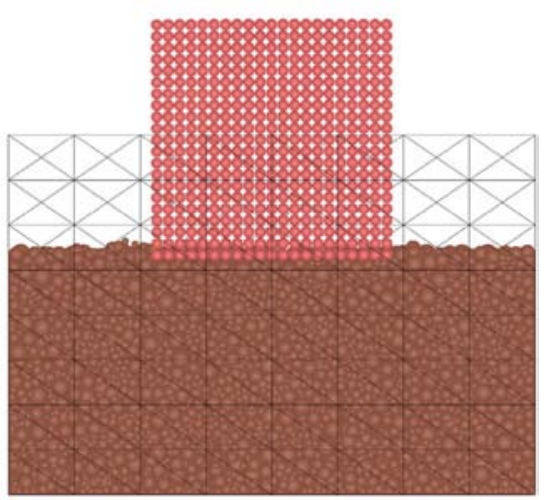

(b) $\mathrm{t}=10.0 \mathrm{~ms}$

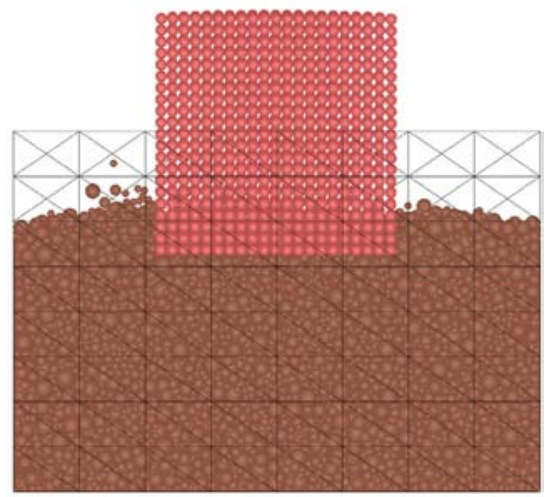

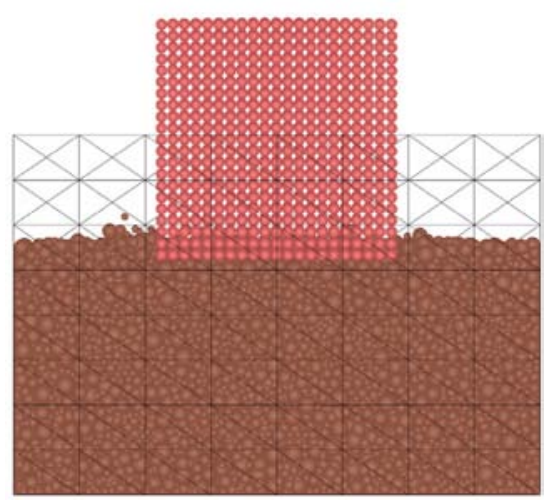

(c) $\mathrm{t}=20.0 \mathrm{~ms}$

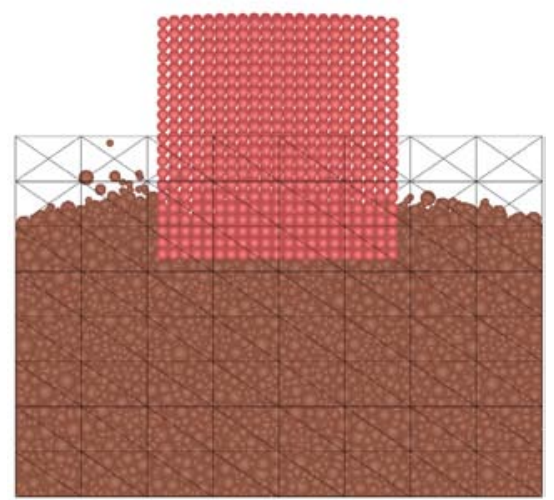

(f) $\mathrm{t}=50.0 \mathrm{~ms}$ 
the scattering particles was confirmed and it it was recognized that the reratively small penetration of the flat weight into the sand cushion and obvious much upsurge of the sand particles around the weight occured.

In order to make movement of particles understandable, time histories of the velocity distribution of sand can be expressed as contour figure and these at center section in the case of JHT50F15 are shown in Fig. 8. The warmer color expresses the larger velocity. As already shown in Fig. 5(e), the largest weight impact force was occurred at $t=3.3 \mathrm{~ms}$, afterward the greatest transmission force was occurred at $t=6.6 \mathrm{~ms}$ and the second peak of the weight impact force occurred because of the reach of the reflection wave from the bottom. This phenomenon also can be understood from the detail observation of thus time history of velocity distribution of sand. Movement of the sand just below the weight tended to dissipate at $t=10.0 \mathrm{~ms}$. At $t=15.0 \mathrm{~ms}$, the weight velocity had nearly disappeared keeping penetration. Afterward, the weight was covered with the sand particles elevated outside the weight. From those investigation, it became clear that this analysis method was effective for understanding a detailed phenomenon of between the sand cushion and the weight that was difficult in experiment.

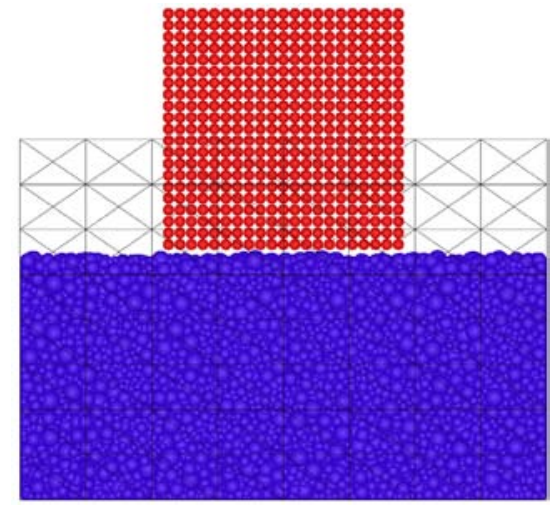

(a) $\mathrm{t}=0.0 \mathrm{~ms}$

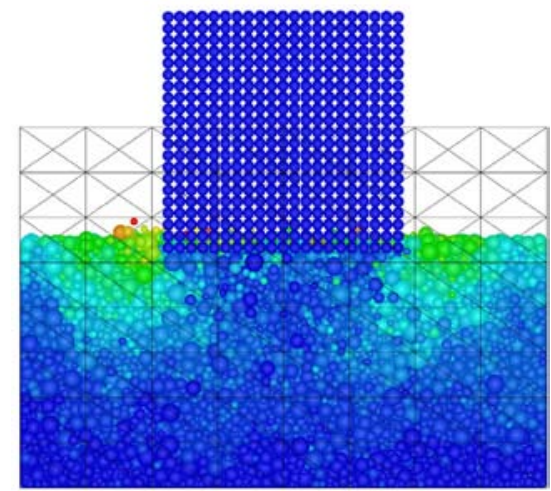

(d) $\mathrm{t}=15.0 \mathrm{~ms}$

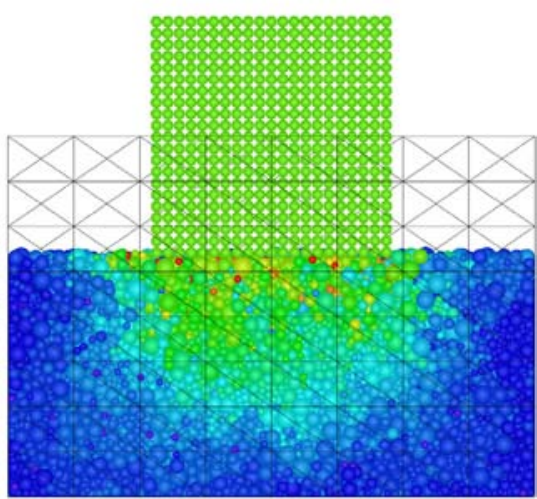

(b) $\mathrm{t}=5.0 \mathrm{~ms}$

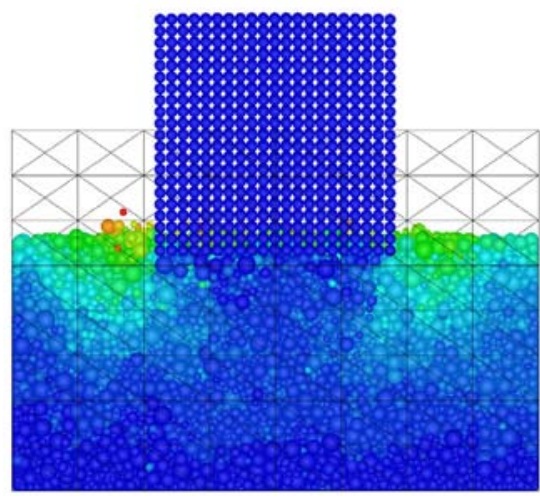

(e) $\mathrm{t}=20.0 \mathrm{~ms}$

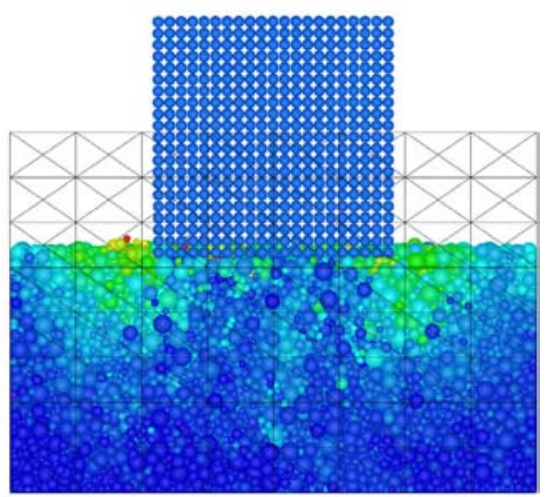

(c) $\mathrm{t}=10.0 \mathrm{~ms}$

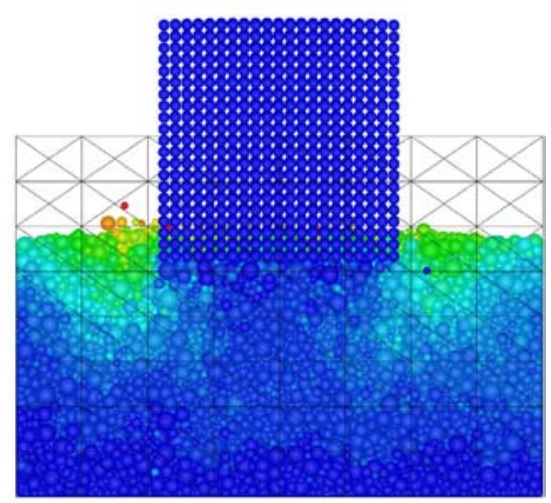

(f) $\mathrm{t}=25.0 \mathrm{~ms}$

Fig. 8 Time histories of the velocity distribution of sand

\section{Summary}

The utilization of highly reliable analysis technique is required to clarify the limit state of a protection structure and carry out performance based design. Consequently, series of impact experiments and numerical analyses using Distinct Element Method were carried out to grasp impact behavior of sand cushion in this study. The conclusions obtained in this research are summarized as follows.

1) The developed technique was concretely shown to express the arbitrary shape of a weight by modeling it in the rigid body of plural particles. It was also shown that the simulation method developed by authors can reproduce an impact force waveform with high precision by the modeling a weight shape in detail. 
2) The method making the sand cushion model by use of random arrangement instead of regular arrangement was shown. Namely, developed model has realistic characteristic expressing the random nature by the analysis of free fall motion to pack sand elements. In addition, it was concretely shown that the method by using the plural particles of the multiple diameters was effective to present the void ratio of the real sand.

3) Reproducibility by developed method in this study was shown comparing impact force waveforms of the analysis with those of experiment. It was shown that there were enough reproducibility in particular concerning the case of flat bottom type

4) It was shown that the weight shape at the contact surface with sand cushion was important to consider the impact force. Influence using convexo-concave surface in the weight model were concretely shown from comparison with experimental results and analytical considerations.

\section{References}

[1] Japan road association "Handbook of preventatives against rock falls", Japan Road Association, 2000.

[2]Japan Railway Civil Engineering Association "Manual for preventive structures against rockFalls”, Japan Railway Civil Engineering Association, 1978.

[3]. Impact Committee of Japan Society of Civil Engineers: Practical methods for impact test and analysis, Japan Society of Civil Engineers, Structural Engineering Series 15, 2004.

[4]. Masuya, H., "Impact problem concerning rock falls and research activities of related field in Japan”, Proc. of 6th Asia-Pacific Conference on shock \& impact loads on structures, pp.63-70, Dec.2005

[5]. Subcommittee concerning performance based design of structures against impact action (edited by Masuya, H.) "Design method of structures under impact action by concept of performance based design”, Structural Engineering Technical Series No.52, Japan Society of Civil Engineers, 2007

[6.] Masuya, H., Kajikawa, Y., "Numerical Analysis of the Collision Between a Falling Rock and a Cushion by Distinct Element Method", Proc. of the Seventh Int. Conf. on Computer Methods and Advances in Geomechanics, Vol.1, 1991, pp.493-498

[7]. Masuya H. and Nakata Y. "Development of numerical model combining distinct element and finite element methods and application to rock shed analysis”, Proceedings of Japan society of civil engineering, No.710/I, pp.113-128, 2002. 